\title{
Strategi Manajemen Konflik Sebagai Upaya Meningkatkan Kinerja Teamwork Tenaga Kependidikan
}

\author{
Sri Wartini \\ Jurusan Manajemen, Fakultas Ekonomi \\ Universitas Negeri Semarang \\ Kampus Sekaran Gunungpati Semarang 50229 \\ e-mail: sriwartini169@gmail.com
}

\begin{abstract}
The purpose of this research is to explain influence of conflict management strategy on teamwork performance. This kind of conflict can happen to everyone and in any places disregarding status, income and position. Someone who can not manage conflicts will have a threat for his personal performance, and unfortunately, company's performance will also gain the effect. Accordingly, we need a strategy to manage conflicts as an effort to create a good performance for individual employee performance as well as the team performance. The population af this research is the entire educational employees in UNNES by taking some samples using propotional sampling to around 88 samples. The result of this research proves that hypothesis stating "conflict management strategy" influenced positively and significantly on teamwork performance is accepted. This explains that conflict management strategy can give contribution to the teamwork performance through employee's ability to accomodate ideas from partners of work, avoid disputes by respecting each other, maintaining communication and conduct colaboration on working methods. It is suggested that this research should improve strategies in managing conflicts such as strategies to compete at work by giving chance to other partner to use theirs skill in making decision and finding solution to solve the job.
\end{abstract}

Keywords: conflict management strategy, teamwork's performance, educational employee

\section{ABSTRAK}

Tujuan penelitian ini adalah untuk menjelaskan pengaruh strategi manajemen konflik terhadap kinerja teamwork. Konflik dapat terjadi pada siapa saja dan dimana saja dengan tidak mengenal status, pendapatan dan kedudukan. Seseorang yang tidak mampu mengelola konflik akan menjadi bumerang bagi kinerja dirinya sendiri dan akhirnya berdampak pula bagi kinerja perusahaan. Dengan demikian dibutuhkan strategi mengelola konflik sebagai salah satu upaya untuk menciptakan kinerja baik untuk kinerja individu karyawan maupun kinerja team. Populasi penelitian ini adalah seluruh tenaga kependidikan di UNNES dengan pengambilan sampel menggunakan proportional sampling sejumlah 88 sampel. Hasil penelitian membuktikan bahwa hipotesis yang menyatakan strategi manajemen konflik berpengaruh secara positif dan signifikan terhadap kinerja teamwork diterima. Hal ini menjelaskan bahwa strategi manajemen konflik dapat memberikan kontribusi pada kinerja teamwork melalui kemampuan karyawan dalam mengakomodir ide dari rekan kerja, kemampuan menghindari perbedaan pendapat dengan menjaga perasaan dan menjaga hubungan komunikasi, dan melakukan kolaborasi tentang metode kerja. Saran penelitian ini hendaknya meningkatkan strategi mengelola konflik seperti strategi berkompetisi dalam bekerja dengan memberikan kesempatan rekan lainnya untuk menggunakan keahliannya dalam membuat keputusan dan menemukan solusi penyelesaian pekerjaan. Kata Kunci: strategi manajemen konflik, kinerja teamwork, tenaga kependidikan 


\section{Pendahuluan}

Salah satu indikator kesuksesan organisasi tercermin pada kinerja yang dihasilkan secara komprehensif, baik kinerja dari aspek finansial, aspek manusia, aspek metode kerja dan lingkungan yang kondusif. Terkait dengan kinerja sumber daya manusia (SDM) dipengaruhi oleh dua katagori faktor utama yaitu faktor internal dan faktor eksternal SDM (Kaushal dan Kwantes 20006). Faktor internal SDM merupakan suatu keadaan atau kondisi yang ada dalam diri individu karyawan dan dapat mempengaruhi secara langsung pada kinerja. Faktor internal tersebut bisa meliputi pengetahuan, semangat, sikap, kepuasan, kedisiplinan, stress, komitmen dan masih banyak lainnya. Hal-hal tersebut tentu saling terkait dan memberikan dampak secara langsung yang signifikan bagi kemajuan organisasi atau lembaga. Begitu pula dengan faktor eksternal di mana suatu kondisi atau keadaan disekitar kita yang secara tidak langsung dapat memberikan pengaruh pada kinerja. Faktor eksternal tersebut meliputi lingkungan kerja, kebijakan pemerintah atau lembaga, adanya persaingan, sistem manajemen lembaga, budaya dan peran pemimpin serta faktor lainnya.

West (2002) dan Tjosvold et al. (2002) mengungkapkan bahwa sebuah organisasi tidak akan berjalan dengan baik jika di dalamnya tidak ada peran pemimpin sebagai orang yang bertanggung jawab atas organisasi tersebut. Pemimpin itu tidak akan maksimal dalam melaksanakan tugasnya tanpa adanya bawahan (karyawan) yang selalu berintraksi dan membantunya. Adanya pemimpin dan bawahan (karyawan) tersebut adalah suatu bukti bahwa organisasi dan struktur saling berkaitan. Oleh karena itu, istilah struktur digunakan dalam artian yang mencakup: ukuran (organisasi), derajat spesialisasi yang diberikan kepada anggota kepada organisasi, kejelasan jurisdiksi (wilayah kerja), kecocokan antara tujuan anggota dengan tujuan organisasi, gaya kepemimpinan, dan sistem imbalan. Sebagai tolak ukur, dalam penelitian menunjukkan bahwa ukuran organisasi dan derajat spesialisasi merupakan variabel yang mendorong terjadinya konflik struktur. Makin besar organisasi, dan makin terspesialisasi kegiatannya, maka semakin besar pula kemungkinan terjadinya konflik (Eisenhardt et al. 1997 dan Tang 2007)

Menurut Eisenhardt et al. (1997) konflik merupakan suatu proses interaksi yang terjadi akibat adanya ketidaksesuaian atau perbedaan antara dua pendapat (sudut pandang), baik itu terjadi dalam ukuran (organisasi), derajat spesialisasi yang diberikan kepada anggota organisasi, kejelasan jurisdiksi (wilayah kerja), kecocokan antara tujuan anggota dengan tujuan organisasi, gaya kepemimpinan, dan sistem imbalan yang berpengaruh atas pihak-pihak yang terlibat, baik pengaruh positif maupun pengaruh negatif. Sedangkan menurut Lambert et al. (2006) konflik merupakan situasi yang terjadi ketika ada perbedaan pendapat atau perbedaan cara pandang di antara beberapa orang, kelompok atau organisasi. Sikap saling mempertahankan diri, sekurang-kurangnya di antara dua kelompok, yang memiliki tujuan dan pandangan berbeda, dalam upaya mencapai satu tujuan, maka mereka berada dalam posisi oposisi bukan kerjasama. Apabila suatu organisasi dengan kaku menolak adanya perubahan, maka situasi konflik yang terjadi tidak akan reda. Tensi akan makin meningkat "suhunya" dan setiap konflik yang baru terjadi akan makin mencerai beraikan sub unit-sub unit organisasi yang bersangkutan (Lambert et al. 2006). 
Dalam proses interaksi antara suatu subsistem dengan subsistem lainnya tidak ada jaminan akan selalu terjadi kesesuaian atau kecocokan antara individu pelaksananya. Setiap saat ketegangan dapat saja muncul, baik antar individu maupun antar kelompok dalam organisasi. Banyak faktor yang melatar belakangi munculnya ketidakcocokan atau ketegangan, antara lain; sifat-sifat pribadi yang berbeda, perbedaan kepentingan, komunikasi yang "buruk", dan perbedaan nilai. Perbedaanperbedaan inilah yang akhirnya membawa organisasi ke dalam suasana konflik. Agar organisasi dapat tampil efektif, maka individu dan kelompok yang saling tergantung itu harus menciptakan hubungan kerja yang saling mendukung satu sama lain, menuju pencapaian tujuan organisasi (Lambert et al. 2006).

Diungkapkan dalam penelitian Irawati (2007) bahwa berbagai perbedaan yang muncul dalam organisasi yang dapat menimbulkan silang pendapat, pertengkaran atau bahkan konflik di dalam tubuh organisasi. Adanya job design dan job description secara otomatis telah memposisikan seseorang sebagai kompetitor bagi sesamanya, sehingga menimbulkan persaingan yang seringkali berakibat buruk bagi kinerja organisasi secara keseluruhan. Saat ini, deskripsi jabatan mulai ditinggalkan dan beralih pada sistem team description. Apabila timbul persaingan bahkan permusuhan yang seharusnya tidak perlu terjadi, maka pimpinan harus dapat memahami apa yang sebenarnya diinginkan oleh anggota organisasinya serta mencoba mengatasi konflik yang muncul tanpa merugikan organisasi itu sendiri. Dengan kata lain manajemen harus mampu memfasilitasi berbagai kegiatan di dalam organisasi agar menghasilkan kinerja yang baik dengan tingkat konflik intern minimal.

Tidak jarang pula pada sebuah organisasi, di dalamnya termasuk mengelola kerjasama tim untuk menyelesaikan pekerjaan. Tim yang solid akan berhasil melaksanakan tugas-tugas organisasi yang diembankan kepada mereka. Mereka memiliki komitmen yang kuat dalam mengimpiementasikan putusan-putusan penting yang telah dirumuskan dan disepakati untuk dilaksanakan secara bersama-sama. Tetapi ada juga sebagian anggota dalam tima atau kelompok yang tidak bisa menyesuaikan dengan lingkungannya untuk bekerja bersama-sama. Orang-orang yang termasuk kategori ini akan menjadi penghambat kemajuan bagi sebuah organisasi (De Dreu dan Weingart 2003).

Aktivitas organisasi dapat efektif apabila individu dan kelompok kerja lainnya ada saling ketergantungan yang dapat menciptakan hubungan kerja saling mendukung satu sama lain, menuju pencapaian tujuan organisasi, berupaya untuk tidak menciptakan perbedaan yang akhirnya akan menjadi sebuah konflik. Untuk menciptakan suasana kerja menjadi lebih kondusif diperlukan suatu strategi dalam mengelola konflik. Kaushal dan Kwantes (2006) mendefenisikan bahwa strategi merupakan rencana kerja suatu perusahaan yang bertujuan untuk menciptakan keunggulan bersaing. Strategi dapat dipandang sebagai suatu alat yang dapat menentukan langkah organisasi baik dalam jangka pendek maupun jangka panjang. Dengan demikian dapat disimpulkan bahwa bahwa strategi sebagai serangkaian aktivitas yang mempertimbangkan aspek tujuan strategis organisasi dengan menggunakan metode yang tepat sasaran dan tepat guna khususnya dalam pengelolaan sumber daya manusia sebagai elemen utama yang memiliki peran penting bagi keberlangsungan kinerja organisasi. 
Strategi pada manajemen konflik diperlukan bagi individu dan kelompok sebagai upaya untuk suatu proses perbaikan hubungan personal yang berkaitan dengan penyelesaian pekerjaan. Menurut Kwantes et al. (2008) dibutuhkan lima strategi mengelola konflik yaitu dengan mewajibkan, mengintegrasikan, menghindari, mendominasi dan mengorbankan serta memberikan dampak pada kinerja personal dan kinerja kelompok.

Perusahaan yang berupaya mengimplementasikan strategi manajemen konflik ternyata mampu menciptakan hubungan kerja yang harmoni dengan adanya saling menghargai perbedaan, mau menerima masukan untuk kebaikan tujuan organisasi, saling menjaga dan menghargai perasaan satu sama lain serta saling membangun komunikasi terbuka dengan penuh keihlasan (Kwantes et al. 2008). Upaya tersebut akan memberikan dampak positif bagi psikis individu dan kelompok kerja karena adanya perasaan kerlibatan dan penghargaan atas kemampuan, keahlian yang dimiliki menjadi termanfaatkan untuk mencapai tujuan yang diharapkan perusahaan/lembaga sehingga sudah tentu hasil upaya tersebut akan berdampak meningkatkan kinerja, baik kinerja individu maupun kelompok kerja. Kinerja dapat didefenisikan sebagai suatu unjuk kerja yang merupakan hasil kerja pegawai individu atau kelompok dimana perilaku nyata yang ditampilkan sesuai dengan perannya dalam organisasi (De Dreu dan Weingart 2003). Sedangkan menurut Sudarma (2012), kinerja diartikan sebagai sesuatu yang dikerjakan baik produk/jasa yang dihasilkan dari seseorang atau sekelompok orang.

Menurut Tjosvold et al. (2002) kinerja tim sesungguhnya dinilai dari kemampuan keharmonisan setiap individu karyawan dalam berbagi tugas pokok dan fungsi pekerjaan kepada rekan kerja lainnya, adanya keterbukaan melalui pemanfaatan komunikasi antar rekan kerja, mempertimbangkan efektivitas dan efisiensi kerja, serta mau menerima metode-metode baru dalam penyelesaian perkerjaan

Tujuan dari penelitian ini adalah menjelaskan pengaruh strategi manajemen konflik terhadap kinerja teamwork, karena disadari atau tidak bahwa konflik dapat menjadi masalah yang serius dalam setiap organisasi, tanpa peduli apapun bentuk dan tingkat kompleksitas organisasi tersebut. Kerjasama (teamwork) merupakan sebuah sistem pekerjaan yang kerjakan oleh dua orang atau lebih untuk mendapatkan tujuan yang direncanakan bersama. Kerjasama dalam tim menjadi sebuah kebutuhan dalam mewujudkan keberhasilan kinerja dan prestasi kerja. Kerja sama dalam tim kerja akan menjadi suatu daya dorong yang memiliki energi dan sinergisitas bagi individu-individu yang tergabung dalam kerja tim. Komunikasi akan berjalan baik dengan dilandasi kesadaran tanggung jawab tiap anggota (Tjosvold et al.2005).

Hasil penelitian West (2002) membuktikan bahwa kerjasama secara berkelompok mengarah pada efisiensi dan efektivitas yang lebih baik. Hal ini sangat berbeda dengan kerja yang dilaksanakan oleh perorangan. Setiap tim maupun individu sangat berhubungan erat dengan kerja sama yang dibangun dengan kesadaran pencapaian prestasi dan kinerja.

Tenaga kependidikan pada Universitas Negeri Semarang (UNNES) merupakan SDM yang memiliki peranan penting untuk mendukung kinerja sivitas akademika, yang berkewajiban memberikan layanan akademik. Dalam pelaksanaan tugasnya, tidak terlepas dari adanya saling ketergantungan bahkan keterkaitan antara unit yang satu 
ke unit yang lain. Jika terdapat kesalahan komunikasi ataupun beda pemahaman, terkadang menjadi sebuah benturan-benturan yang mengakibatkan konflik misalnya saja adanya miskomunikasi antar tim kerja dan atasan dalam menerima atau mengartikan pesan, sehingga menjadi tidak jelas dan tidak tepat, adanya perbedaan metode atau cara menyelesaikan pekerjaan, sementara ketidaksesuaian akan memberikan dampak pada kinerja baik secara individu maupun tim kerja. Kondisi ini selaras dengan pendapat Gibson bahwa manajemen konflik selain dapat menciptakan kerjasama, hubungan saling tergantung ternyata dapat pula melahirkan konflik. Hal ini terjadi jika masing-masing komponen organisasi memiliki kepentingan atau tujuan sendiri-sendiri dan tidak saling bekerjasama satu sama lain. Konflik dapat menjadi masalah yang serius dalam setiap organisasi, tanpa peduli apapun bentuk dan tingkat kompleksitas organisasi tersebut. Konflik tersebut mungkin tidak membawa "kematian" bagi organisasi, tetapi pasti dapat menurunkan kinerja organisasi yang bersangkutan, jika konflik tersebut dibiarkan berlarut-larut tanpa penyelesaian.

Bertolak dari fenomena di atas, diperlukan sebuah strategi dalam mengelola konflik agar tidak menimbulkan kerugian bagi semua pihak seperti kerugian psikis pribadi karyawan itu sendiri, kerugian nilai hubungan dengan rekan sekelompok kerja serta kerugian bagi lembaga organisasi secara keseluruhan. Pengelolaan konflik dengan efektif bagi karyawan akan menghasilkan hubungan yang positif dan kondusif dimana pengelolaan tersebut mampu menciptakan keharmonisan dalam bekerja. Adanya saling membutuhkan antar rekan kelompok kerja dengan kata lain rasa ketergantungan sangat dirasakan bagi sekelompok karyawan sebagai satu kesatuan tim dalam bekerja, dan secara keseluruhan tentunya akan meningkatkan kinerja tim (Irawati 2007). Permasalahan dalam penelitian ini adalah untuk mengetahui penerapan strategi manajemen konflik dan pengaruhnya terhadap kinerja teamwork pada tenaga kependidikan di lingkungan Universitas Negeri Semarang.

Untuk menciptakan dan meningkatkan kinerja baik individu maupun tim, diperlukan strategi dalam mengelola konflik agar tidak menimbulkan kerugian bagi semua pihak seperti kerugian psikis pribadi karyawan itu sendiri, kerugian nilai hubungan dengan rekan sekelompok kerja serta kerugian bagi perusahaan/lembaga organisasi secara keseluruhan (Tang 2007). Dengan demikian maka hipotesis yang di ajukan adalah :

Ha: strategi manajemen konflik berpengaruh secara positif dan signifikan terhadap kinerja teamwork.

\section{Metode Penelitian}

Populasi dalam penelitian ini adalah seluruh tenaga kependidikan dilingkungan Universitas Negeri Semarang (Unnes) yang masih aktif bekerja sejumlah 721 orang dari 10 unit kerja. Setelah jumlah besaran populasi diketahui dengan pasti maka dalam penentuan jumlah sampel menggunakan penghitungan rumus Slovin diperoleh 88 orang yang menjadi reponden. Teknik pengambilan sampel menggunakan proportional sampling dimana anggota atau unsur populasi penelitian ini tidak homogen dan berstrata secara proposional (Sugiyono 2003). 
Variabel penelitian yang digunakan dalam penelitian ini terdiri dari strategi manajemen konflik $(x)$ dengan indikator yang dikembangkan meliputi menghindari, mengakomodasi, kompetisi, mengkompromikan dan mengkolaborasikan. Sedangkan variabel terikat dalam penelitian ini adalah kinerja teamwork $(\mathrm{Y})$ dengan indikator keharmonian kerja, komunikasi terbuka, cara menyelesaikan pekerjaan, kerjasama dan peran kepemimpinan.

Berbagai pengelolaan konflik (manajemen konflik) yang efektif dalam penjelasan Robbins dan Hunsaker (1996) dan Kaushal dan Kwantes (2006) adalah dengan melakukan berbagai upaya dengan menghindar terciptanya konflik, mengakomodasi konflik yang ada, menggunakan kompetisi untuk memanfaatkan konflik menjadi kegiatan yang positif, melakukan kompromi, dan mampu mengkolaborasikan pendapat atau ide yang berbeda menjadi sebuah masukan atau solusi untuk memecahkan masalah. Upaya-upaya tersebut menurut penelitian yang dilakukan Irawati (2007) membuktikan adanya peningkatan yang signifikan terhadap kinerja kelompok melalui keharmonian kerja, komunikasi terbuka, cara menyelesaian pekerjaan, mempertimbangkan efektivitas dan efisiensi kerja. Keterkaitan variabel-variabel tersebut dapat dibangun model penelitian seperti pada Gambar 1.

\begin{tabular}{|c|c|}
\hline Strategi Manajemen Konflik (X) & Kinerja Teamwork $(\mathrm{Y})$ \\
\hline 1. Menghindar & 1. Keharmonian Kerja \\
\hline 2. Mengakomodasi & 2. Komunikasi terbuka \\
\hline 3. Kompetisi & 3. Cara penyelesaian kerja \\
\hline 4. Kompromi & 4. Efektifitas kerja \\
\hline 5. Kolaborasi & 5. Efisiensi kerja \\
\hline
\end{tabular}

Gambar 1. Model penelitian

\section{Hasil dan Pembahasan}

Pengujian intrumen dilakukan menggunakan uji validitas dan reliabilitas dengan pengukuran skala Likert terhadap 32 item kuesioner mengenai strategi manajemen konflik dan kinerja teamwork. Dari hasil uji validitas intrumen, dapat diketahui bahwa semua item kuesioner memiliki nilai signifikansi < sig yang diisyaratkan 0.05 maka dapat simpulkan bahwa semua hasil item instrumen adalah valid dan layak digunakan dalam penelitian ini.

Berdasarkan hasil uji realibilitas dapat diketahui untuk semua variabel penelitian yang telah diuji hasilnya adalah reliabel (handal), dimana nilai alpha hitung masingmasing variabel $>0.60$. Sehingga dapat disimpulkan bahwa kuisioner tersebut handal digunakan dalam penelitian.

Hasil pengujian regresi linear sederhana dilakukan untuk melihat sejauh mana strategi manajemen konflik mempengaruhi terhadap kinerja teamwork. Hasil analisis Regresi dapat dilihat pada Tabel 1. 
Tabel 1. Hasil uji regresi

\begin{tabular}{lcccc}
\hline \multicolumn{1}{c}{ Koefisien } & B & $\boldsymbol{\beta}$ & t & Sig t \\
\hline Konstanta & 35.065 & & 6.669 & 0.000 \\
Strategi Manajemen Konflik & 0.447 & 0.506 & 5.437 & 0.000 \\
F & - & - & 29.557 & - \\
Sig F & - & - & 0.000 & - \\
$\mathrm{R}^{2}$ & - & - & 0.558 & - \\
\hline
\end{tabular}

Sumber : Data diolah

Dari hasil tersebut (Tabel 1) dapat dijelaskan bahwa diperoleh Nilai Konstanta (a) adalah 35.065 ini berarti jika strategi manajemen konflik diasumsikan tetap (0) maka kinerja teamwork adalah sebesar 35.065. Sedangkan untuk Nilai koefisien regresi variabel strategi manajemen konflik (b) diperoleh sebesar 0.447 , artinya bahwa setiap ada peningkatan strategi manajemen konflik akan diikuti dengan peningkatan kinerja teamwork.

Hasil pengujian hipotesis dapat dijelaskan bahwa diperoleh nilai Signifikansi strategi manajemen konflik sebesar $0.000<0.05$, maka hasil ini membuktikan penolakan terhadap Ho dan penerimaan Ha dimana strategi manajemen konflik berpengaruh secara positif dan signifikan terhadap kinerja teamwork sepenuhnya diterima. Hasil pengujian kontribusi variabel penelitian dengan uji determinasi dapat dilihat pada Tabel 2.

Tabel 2. Hasil uji determinasi

\begin{tabular}{ccccc}
\hline \multicolumn{5}{c}{ Model Summary } \\
\hline Model & $\mathrm{R}$ & R Square & Adjusted R Square & Std. Error of the Estimate \\
\hline 1 & $.506^{\mathrm{a}}$ & .558 & .471 & 4.179 \\
\hline
\end{tabular}

a. Predictors: (Constant), TotX

Bedasarkan hasil tersebut, diketahui nilai $\mathrm{R}^{2}$ sebesar 0.558 atau $55.8 \%$. Hal ini berarti persentase kontribusi pengaruh strategi manajemen konflik terhadap kinerja teamwork adalah sebesar $55.8 \%$ sedangkan sisanya $44.2 \%$ dipengaruhi oleh variabel lain yang tidak dimasukan dalam model ini. Dari hasil pengujian tersebut dapat dijelaskan bahwa strategi manajemen konfilk mampu mempengaruhi kinerja teamwork melalui 4 indikator dimana karyawan terbukti mampu mengakomodir saransaran yang masuk dari rekan kerja lainnya, saling menjaga perasaan serta kerelaan dalam membantu rekan kerja, adanya kemampuan karyawan dalam mengkolaborasikan gagasan dengan gagasan orang lain guna mendapatkan solusi yang diharapkan, hasil ini ternyata dapat menciptakan kinerja yang baik di antara keduanya (baik bagi individu maupun kelompok kerjanya). Hal lainnya yang penting dalam mengelola konflik adalah aktivitas menghindari perbedaan pendapat yang tidak menyenangkan dan menjaga komunikasi pada pihak lain yang tidak ada relavansinya dilakukan juga secara kesinambungan dan terintegritas pada unit kerja lainnya sehingga tujuan perusahaan dapat berjalan dengan efektif dan efisien. Hasil ini sejalan dengan pendapat Eisenhardt et al. dalam Robbins dan Hunsaker (1996) dan De Dreu dan Weingart (2003) bahwa untuk menjaga kinerja individu seseorang dan kelompok kerjanya pada sebuah organisasi dibutuhkan suatu strategi manajemen konflik melalui 
lima aktivitas seperti menghindari, mengakomodasi, mengkompromikan, mengkompetisikan dan berkolaborasi.

1. Menghidari (Avoiding)

Seseorang atau organisasi cenderung untuk menghindari terjadinya konflik. Hal-hal yang sensitif dan potensial menimbulkan konflik sedapat mungkin dihindari sehingga tidak menimbulkan konflik terbuka.

2. Mengakomodasi (Accomodating)

Anggota tim mau mengumpulkan dan mengakomodasikan pendapat-pendapat dan kepentingan pihak yang terlibat konflik, selanjutnya dicari jalan keluarnya dengan tetap mengutamakan kepentingan pihak lain atas dasar masukan-masukan yang diperoleh.

3. Mengkompromikan (Compromising)

Penyelesaian konflik dengan cara melakukan negosiasi terhadap pihak-pihak yang berkonflik, sehingga kemudian menghasilkan solusi (jalan tengah) atas konflik yang sama-sama memuaskan (lose-lose solution).

4. Berkompetisi (Competing)

Pihak-pihak yang berkonflik saling bersaing untuk memenangkan konflik, dan pada akhirnya harus ada pihak yang rela dikorbankan (dikalahkan) kepentingannya demi tercapainya kepentingan pihak lain yang lebih kuat atau yang lebih berkuasa (winlose solution).

5. Mengkolaborasikan (Collaborating)

Pihak-pihak yang saling bertentangan akan sama-sama memperoleh hasil yang memuaskan, karena mereka justru bekerjasama secara sinergis dalam menyelesaikan persoalan, dengan tetap menghargai kepentingan pihak lain, sehingga kepentingan kedua pihak tercapai (menghasilkan win-win solution).

Dengan demikian pengelolaan konflik terbukti mampu memberikan kontribusi secara umum pada kinerja teamwork perusahaan. Hal ini terlihat pada terciptanya keharmonian kerja, adanya keterbukaan dalam komunikasi, penggunaan metode penyelesaian kerja yang tepat, serta mempertimbangkan efektivitas dan efeisiensi kerja yang mendukung teamwork. Sedangkan pada indikator kompetisi belum sepenuhnya dilakukan. Hal ini terlihat pada jawaban responden terkait dengan melibatkan keahlian orang lain pada teamwork yang masih rendah.

Hasil ini secara keseluruhan konsisten dengan tinjauan literatur terdahulu yang diungkapkan oleh West (2002), Tjosvold et al. (2002), Irawati (2007) dan Eisenhardt et al. (1997) dimaknai bahwa pengelolaan konflik bagi kerjasama tim akan menghasilkan hubungan yang positif dan kondusif di mana pengelolaan tersebut mampu menciptakan keharmonisan dalam bekerja dan adanya saling membutuhkan antar rekan kelompok kerja. Dengan kata lain, rasa ketergantungan sangat dirasakan bagi karyawan sebagai satu kesatuan tim dalam bekerja, seperti menerapkan komunikasi yang terbuka serta mempertimbangkan efektivitas dan efisiensi kerja. Bila hal ini dilakukan dengan benar, maka akan mampu meningkatkan kinerja dan citra lembaga. 


\section{Kesimpulan}

Dapat disimpulkan dari hasil analisis dan pembahasan bahwa strategi manajemen konflik berpengaruh secara positif dan signifikan terhadap kinerja teamwork tenaga kependidikan. Hal ini menunjukkan bahwa semakin baik strategi manajemen konflik dilakukan akan semakin dapat meningkatkan kinerja teamwork tenaga kependidikan yang hasilnya dapat diukur melalui terciptnya keharmonian kerja, terjalinnya komunikasi yang terbuka, adanya pertimbangan akan efektivitas dan efisiensi kerja serta terbuka dalam penggunaan metode-metode untuk membantu dalam penyelesaian pekerjaan.

Saran yang bisa diberikan pada pimpinan (manajer) bahwasanya megelola konflik pekerjaan diperlukan strategi efektif untuk mengelola konflik agar tidak menjadi hambatan dalam meningkatkan kinerja baik kinerja individu maupun kinerja tim dengan cara menghindari, mengakomodasi, mengkolaborasi, dan melakukan kompromi. Sedangkan pada strategi kompetisi, pihak lembaga dalam hal ini adalah pimpinan hendaknya memberikan kesempatan pada rekan kerja lainnya untuk menunjukan keahliannya dengan membatu membuat keputusan atau menemukan solusi yang tepat dari aktivitas tersebut, pimpinan akan dapat melihat kinerja antar individu yang terbaik karena setidaknya melalui pemberian kesempatan yang sama secara tidak langsung kita telah ikut menilai dan mengevaluasi karakteristik dan kinerja masing-masing individu karyawan. Kesempatan ini juga akan membuat karyawan bepikir positif terhadap karyawan lainnya.

Saran untuk peneliti selanjutnya adalah perlunya dikembangkan dan dipertimbangkannya strategi atau orientasi lain untuk mengelola konflik pekerjaan. Hal ini dilakukan dengan cara menambah variabel etika kerja pada tenaga kependidikan yang merupakan satu satuan tim kerja dalam sebuah organisasi, sehingga dapat membantu dalam pengendalian pengelolaan konflik secara langsung. Hal ini tidak hanya mempertimbangkan orientasi psikologi karyawan dan orientasi pada tugas saja, melainkan juga memahami norma yang berlaku dalam bekerja yang pada akhirnya memberikan dampak pada ketercapaian kinerja teamwork dan kinerja lembaga. Perlu pula dikembangkan penelitian yang lebih luas misalnya tidak hanya di kalangan tenaga kependidikan, tetapi kalangan dosen agar lebih mengeneralisasi dan mengetahui variasi pengelolaan konflik di sebuah lembaga perguruan tinggi sehingga kajian manajemen konflik ini menjadi lebih beragam dan mengetahui perbedaan hasil penelitian.

\section{Daftar Pustaka}

De Dreu CKW, Weingart LR. 2003. Task versus relationship conflict, team performance, and team member satisfaction: a meta analysis. Journal of Applied Psychology, 88(4): 741-749.

Eisenhardt KM, Jean LK, Bourgeois III L. 1997. Conflict and strategic choice: how top management team disagree. California Management Review, 39(2).

Irawati D. 2007. Manajemen konflik sebagai upaya meningkatkan kinerja teamwork dalam organisasi. Segmen Jurnal Manajemen Bisnis, (2): 15-27. 
Kaushal R, Kwantes CT. 2006. The role of culture and personality in choice of conflict management strategy. International Journal of Intercultural Relations, 30(5): 579-603.

Kwantes CT, Karam CM, Kuo BCH, Towson S. 2008. Organizational citizenship behaviors: The influence of culture. Journal of Intercultural Relations, 32 : 229243.

Lambert EG, Pasupileti S, Cluse-Tolar T, Jennings M, Baker D. 2006. The impact of work-family conflict on social work and human service worker job satisfaction and organizational commitment. An exploratory study. Administration in Social Work, 30(3): 55-74.

Robbins SP, Hunsaker PL. 1996. Training in Interpersonal Skill: Tips for Managing People At Work. Edisi 2. Jersey (US): Prentice Hall.

Sudarma K. 2012. Strategi Membangun Kompetensi Terhadap Kinerja Organisasi Dampaknya Pada Pembelajaran Organisasi. Semarang (ID): Unnes.

Sugiyono. 2003. Metode Penelitian Bisnis. Cetakan kelima. Bandung (ID): CV. Alfabeta.

Tang HC. 2007. A study of the relationship of the perception of oragnizational promises among fakulty and staff members in the technical and vocational colleges. The Journal of American Academy of Business, Cambridge, 12(1).

Tjosvold D, Chun Hui, Ziyou Yu. 2002. Conflict management and task reflexivity for team in role and extra role performance in China. Hong kong Institute of Business Studies Working Paper Series. Paper 36.

Tjosvold D, Poon M, Yu Z. 2005. Team effectiveness in China: cooperative conflict for relationship building. Human Relations, 58(3): 341-367.

West M. 2002. Sparkling fountains or stagnant ponds: An integrative model of creativity and innovation implementation in work groups. Applied Psychology: An International Review, 51(3): 355-424. 